\title{
Maimonides and the Convert: A Juridical and Pbilosophical Embrace of the Outsider
}

\author{
JAMES A. DIAMOND \\ University of Waterloo
}

Within the long tradition of halakhic stares decisis, or Jewish responsa literature, one can find no more intricate a weave of law and philosophy than that crafted by the twelfth century Jewish jurist and philosopher, Moses Maimonides, in response to an existential query by Ovadyah, ${ }^{1}$ a Muslim convert to Judaism. ${ }^{2}$ Ovadyah's conversion raised particular concerns within the realm of institutionalized prayer and the rabbinically standardized texts that were its mainstay. The liturgy that had evolved was replete with ethnocentric expressions that rendered it highly resistant to the entry of outsiders anxious to become full-fledged members of the club. How can the convert utter the phrase "God of our fathers" when his biological ancestry belies its pronouncement? What right does he have to lay claim to a divine election, "who chose us," which was motivated by a preference for one "nation" over others? Can he appeal to a God who is particularized as a national liberator, "who took us out of Egypt," when enslavement and exodus were confined to a specific locale and time within a national historical consciousness? And finally, God's intrusion into history on Israel's behalf "who performed miracles for our fathers," is a shared collective memory about which the

1. Ovadyah may have been a name of choice for converts to assume since there was a Talmudic tradition that the biblical prophet Ovadyah was an Edomite proselyte in BT, Sanhedrin 39b. I thank Dr. Tibi Judah for this reference.

2. The letter is one of a series of three responses on different issues to Ovadyah and was most probably written in Hebrew. They appear in both Teshuvot HaRambam, ed., trans., J. Blau (Jerusalem, Mekize Nirdamim, 1958) nos. 293, 436 and 448 and vol. 1 of Iggerot HaRambam, ed., trans. Y. Shilat, Jerusalem, who believes they all form parts of the same correspondence. All references herein are to Shilat's rendering as 'Shilat.' An English translation is available in A Maimonides Reader, ed., I. Twersky (New York, Behrman House, 1972) pp. 475-76. Menahem Kellner's well developed thesis regarding Maimonides' non-essentialist view of the Jewish people (as opposed, for example, to Judah Halevi and the Zohar) forms the basis out of which my study has grown. See his Maimonides on Judaism and the Jewish People (SUNY Press, Albany, 1991) and especially ch. 6.

Thanks are due to Menachem Kellner for taking the time to review an earlier draft of this study. His insightful comments have been incorporated into its present form. 
convert cannot reminisce. This was no mere halakhic question as to whether he could legitimately adopt these communal liturgical expressions. Ovadyah was also posing a deep existential suspicion that he would never be able to consider himself an authentic insider of the religious community he had joined, in all likelihood, at great personal risk. ${ }^{3}$

The problem of a fixed liturgy geared to common origins is particularly acute for the convert for a number of reasons. Firstly it is the most pervasive and dominant feature of the Jewish ritual system of mitzvoth. The entire daily cycle is measured in terms of prayer intervals and blessing opportunities. The observant Jew's calendar is governed by its frequency and appointed times. Secondly, the Rabbis considered it a "worship of the heart," ${ }^{4}$ which replaced the most prominent feature of ancient Judaism, the Temple sacrificial cult. ${ }^{5}$ Praise, supplication, entreaty, appreciation, contemplation, virtually every facet of one's relationship with God is articulated through prayer. ${ }^{6}$ What the Rabbis had in mind by "worship of the heart" is philosophically identified by Maimonides as the apex of human religious activity, "setting thought to work on the first intelligible and devoting oneself exclusively to this as far as this is within one's capacity." ${ }^{7}$ Despite its esoteric formulation of

3. Under Islamic law conversion from Islam to another faith was considered to be an act of apostasy, punishable by death. Though there could be many motivations of a utilitarian nature to convert to dominant ruling religions such as Islam or Christianity there was usually only one going the other way, sincere belief. As D. Wasserstein points out in "A Fatwa on Conversion in Islamic Spain," in Studies in Muslim-Jewish Relations, vol. 1, ed. R. Nettler (Harwood Academic Pub., Switzerland, 1993) pp. 177-88 at pp. 179-80, the draconian penalties for apostasy in countries under Islamic rule "made all reasons except one for conversion to a different faith totally irrelevant. That one exception was, of course, sincere belief." For documented instances of the hardships and persecution endured by converts to Judaism in the Middle Ages see those culled from the Genizah by S. D. Goitein in A Mediterranean Society, vol. ii (Univ. of California Press, Berkely, 1999) pp. 299-311 and especially his observation on p. 304 that "Maimonides' favorable attitude toward proselytizing is echoed in the Geniza documents, in which converts to Judaism are mentioned far more frequently than Jews adopting Islam."

4. B.T., Taanit, 2a.

5. See B.T., Berakhot, 26b; Maimonides, Mishneh Torah (MT), Hilkhot Tefillah 2:5 and Sifrei, Ekev 41.

6. See MT, ibid 1:2; For a Hasidic formulation of prayer as an expression of Being see Pinhas of Koretz, Midrash Pinhas (Jerusalem, 1953)\# 52 "Prayer itself is God, for it is written "Your prayer is your God (Deut. 10:21)," For two modern perspectives of thinkers who occupy polar extremes on the plane of Jewish observance see the excerpt from Abraham Isaac Kook's commentary on the Siddur, Olat R'iyah, as translated by Jacob Agus in Banner of Jerusalem, (Bloch Pub, N.Y., 1946) pp. 217220, "Man uplifts all creation with himself in prayer.... uplifts and exalts the All to the source of blessing and the source of life," and Martin Buber, "If to believe in God means to talk about Him in the third person, then I do not believe in God. If to believe in God means to be able to talk to God, then I do believe in God" in Meetings (LaSalle, Ill., 1973) p. 44.

7. Guide of the Perplexed, (GP), trans., S. Pines, (Chicago, 1963), III:51, p. 621. 
pure contemplation in the Guide, concrete prayer is valued as a step in the evolution toward its realization. ${ }^{8}$ Therefore, to diminish access to its domain for any Jew within a Jewish context is to impede the process of achieving the single minded "devotion" Maimonides determined as a perfected "worship of the heart."

Finally, the response also indicates Ovadyah's concerns as to his role in the public sphere as well as private. The response specifically makes no distinction between private prayer or prayer in the capacity of a shaliach tsibbur (prayer leader or, in contemporary terms, the cantor). ${ }^{9}$ No starker image of the convert's alienation could be drawn than one where the prayers of the prayer group's appointed representative are at odds with the group. It also accentuates the problematics of exclusion from a ritual whose essential characteristic is in fact communal. Prayer functions ideally only within the group. ${ }^{10}$ Indeed, the primary focus of the rabbinic maxim that "every act of sanctification requires not less than ten"11 is directed toward prayer and benedictions. The very verse from which this rule is derived places God within the group, "that I may be sanctified in the midst of the Israelite people" (Lev. 22:32). It confines sanctity to the community. ${ }^{12}$ What qualifies a shaliach tsibbur is his ethical and intellectual constitution, not his ethnic background. ${ }^{13}$ Therefore, any mark of distinction borne by the ger, that is halakhically irrelevant to his qualifications as an emissary of the group, would serve to spotlight his "otherness" and delegitimize his capacity to personify the group. ${ }^{14}$

Motivated by the ethics of acceptance, Maimonides extended a philosophical and halakhic welcome to Ovadyah that fully integrated him into the fabric of the community of Israel. The convert's ancestry can be conceptually traced back to Abraham by replacing the biological father-son model with a pedagogical teacher-disciple one. Abraham is the founder of Israel because he conveyed universal truths through the medium of reasoned instruction. Abraham's language was educatory for "he taught the people, and enlightened them and informed them the true way and

8. This is Marvin Fox's position in "Prayer in the Thought of Maimonides," in Prayer in Judaism, eds. G. Cohn, H. Fisch, (Jason Aaronson, Northvale, 1996) pp. 119-141, at pp. 135-136; "Ordinary prayers and fulfillment of mitzvoth serve as a propadeutic, a discipline which guides and prepares us for the life of true worship."

9. Shilat, p. 233, line 13.

10. BT, Berakhot 8a; MT, Hilkhot Teftillah 8:1.

11. BT, Megillah 23b.

12. Ibid, and MT, Hilkhot Tefillah 8:6.

13. MT., ibid 8:11.

14. Community as a vital feature of prayer is captured in his customary elegant fashion by A. J. Heschel in his discussion of "Prayer and the Community," "What we do as individuals is a trivial episode; what we attain as Israel causes us to become a part of eternity... We never pray as individuals, set apart from the rest of the world. The liturgy is an order which we can enter only as a part of the Community of Israel," in Man's Quest for God (Charles Scribner, N.Y., 1954) pp. 45-46. 
the unity of God... he gave them counsel and advice..."15 Maimonides here draws upon his own portrait of Abraham in the Mishneh Torah as the Socrates of his age who missionizes by "sowing doubt," "engaging in debate," "informing," "overpowering with demonstration," "accumulating a following," informing each follower "in accordance with his capacity," and ultimately "authoring treatises." 16 His legacy of "conversion" to the truth by way of "speech and teaching"17 extends to every future convert. A figurative father/son relationship has been established in the sense offered by the Guide for the Hebrew term 'son' that "whoever instructs an individual in some matter and teaches him an opinion, has, as far as his being provided with this opinion is concerned, as it were engendered that individual."18

Ironically, what allows the convert to assume the ethnocentric language of his newly adopted faith is not his acceptance of its unique command structure (mitzvoth). That was never Abraham's legacy. Rather it is the embrace of those universal truths discovered and propounded by Abraham that eases the convert's entry into the community of Israel. Abraham professed, "the unity of God, rejected idolatry and abolished its worship," 19 that is he promoted universal truths while discrediting popular ideologies of falsehood. This teaching is what attracted large numbers of people to be domiciled "under the wings of the Divine Presence (kanfe hashekhina)."20 Maimonides' introductory deference to Ovadiah is understandably then a verbatim quote of Ruth 2:12, originally addressed to the classic Rabbinic archetype of all converts, Ruth the Moabite, "May the Lord compensate him for his work and may he be granted the perfect reward by the God of Israel under whose wings he has sought shelter." ${ }^{21}$ Ovadyah's journey toward Judaism is quite

15. Shilat, p. 233, lines 14-15; p. 234 line 2.

16. MT, Hilkhot Avodat Kokhavim, 1:3. For a parallel passage in the Guide see II:39, p. 379 where Abraham is described as having "assembled the people and called them by way of teaching and instruction to adhere to the truth that he had grasped... attracting them by means of eloquent speeches and by means of the benefits he conferred upon them."

17. Shilat, p. 234, lines 5-6.

18. Guide, I:7, p. 32; This parallels another analogy drawn between Abraham and his followers as a rock hewn from a quarry in Guide I:16, p. 42. See also MT, Talmud Torah 1:2 for the same model of teacher as parent and the same prooftext as the Guide. The rabbinic source for the halakhic identity of students and children is Sifre, VaEtchanan 33. This notion actually manifested itself on a personal level when Maimonides addressed his students as his sons. See for instance his letter to his student, Joseph ben Judah, in Iggerot LeRabbenu Mosheh ben Maimon, ed., trans. (Heb.) J. Kafih (Mossad HaRav Kook, Jerusalem) p. 125.

19. Shilat, p. 233, lines 14-15. These are precisely what Maimonides mandates all prospective converts to be informed of in MT, Hilkhot Issure Biah, 14:2.

20. Shilat, ibid.

21. See BT, Yebamot, 47b. Maimonides adopts the phrase kanfei shekhina as the destination of all authentic converts in MT, ibid 13:4, as well as the captive woman who is sincere about switching faiths in MT, Hilkhot Melakhim 8:5. See also Guide I:43 for the citation of Ruth 2:2 as an illustration of a figurative sense of "wing" (kanaph). 
literally a reenactment of the originating moment that ultimately gave birth to it. The irrefutable demonstrations crafted by Abraham have traversed time and spoken to the convert by virtue of which he becomes Abraham's disciple and, ipso facto, his descendant.

The prooftext cited in the response, Gen. 18:19, is vital for concisely formulating the substance of Abraham's teaching "For I have known him, to the end that he may command his children and his household after him that they may keep the way of the Lord (derekh yhvh)." The way of the Lord propagated by Abraham is defined by Maimonides in his Mishneh Torah as instruction in the ethical golden mean, which, once inculcated into one's constitution, is the fulfillment of imitatio dei. ${ }^{22}$ Behavioral imitatio dei is merely concomitant to a philosophically pure conception of God and the world. Correct conduct mirrors those attributes we associate with the manner in which nature operates, "attributes of action," not God's essence itself..$^{23}$ Repetitive conduct that is consonant with those traits (mercy, graciousness, holiness, etc.) serves to entrench a correct conception of God within the mind. In accordance with Herbert Davidson's seminal analysis, the ultimate performance of "walking in His ways" is not the mere cultivation of intermediate character traits as tentatively proposed in the Mishneh Torah. Rather it is "by performing acts, as God does, not through intermediate, or any other psychological characteristics, but wholly dispassionately." 24

In this sense, the convert does not only achieve parity with the naturally born Jew but he actually gains an advantage over him. Given the familial background of the latter, his fulfillment of imitatio dei will always be tainted by an ulterior motivation. The emotional and psychological impetus for following in the footsteps of one's father is ever-present and is, in effect, an obstacle to acting in accordance with the dictates of pure reason. The

The case of the biblical Ruth is paradigmatic of the diametric opposition between the rationalist camp typified by Maimonides and that of the kabbalistic school on the status of the proselyte. A recurrent theme in the latter is its ontological inferiorization of the proselyte often ascribed to a different origin of his soul on the sefirotic hierarchy from that of the naturally born Jew. Ruth is but one example of this view which has her introduce her ontological Moabiteness into the metaphysical genetics of Israel upon conversion. See the general discussion of Jochanan Wijnhoven in "The Zohar and the Proselyte," Readings on Conversion to Judaism, ed., L. J. Epstein (Jason Aaronson, N.J., 1995) pp. 47-65 and on Ruth in particular at pp. 60-62. Another popular conception of the proselyte among kabbalists was that they were in fact "Jews" all along. At some point in the past their souls were exiled due to some ancestral apostaty or foreign captivity. Conversion was therefore perceived as a repatriation of a Jewish soul to its proper place. See M. Hallamish, "Some Aspects of the Attitudes of the Kabbalists Toward Gentiles," in Philosophiah Yisraelit, eds., A. Kasher, M. Hallamish (Tel Aviv: Papyrus, 1983)(Heb.) pp. 49-71 at pp. 56-57.

22. See Deot 1:10-12.

23. See the discussion of divine attributes in the Guide I:51:52.

24. PAAJR, 54 (1987): 31-72, at p. 67. 
convert, on the other hand, has no such ties. Like Abraham he has "no one to teach him and no one to instruct him in anything" since his parents, as well as himself, practiced an alien faith. ${ }^{25}$ Maimonides' precise categorization of those who can be considered "disciples of Abraham" now becomes apparent. As a consequence of Gen. 18:19 they are "all those who will convert in the future and all those who profess the unity of God's Name as it is prescribed by the Torah." ${ }^{26}$ Loyalty to family and biological antecedents do not qualify for student status. In addition, the mitzvah to declare God's unity as outlined in the very beginning of the Mishneh Torah does not imply obedience to law. It actually entails piercing through the literal. That can only be realized by way of a detached and reasoned Abrahamic conception of God. Biblical language, which literally prescribes an adulterated God, must be reread to conform to a pure demonstrable notion of unity. ${ }^{27}$ In effect, one must overcome the obstacle of family (parents) and tradition (texts) to be accredited as a "student of Abraham." The convert conforms to both of these requirements.

Maimonides quite consistently maintains a strict distinction between two relational models of Abraham and posterity. He concludes, "it follows then that Abraham, our father, is father to all his pious descendants (zaro) (i.e. only those among his descendants who are pious) who walk in his ways and father to his students (talmidav) and they are every convert who adopts Judaism." 28 There are "students" and there are "descendants," and the former is singled out as the class to which the convert belongs. Only one who did not possess his own tradition qualifies as "student" since his attraction to Judaism could only have materialized out of detached and reasoned study. Even biological descendants do not automatically qualify as Abraham's children but must earn the pedigree by "walking in his ways." This latter phrase subtly draws attention to the disadvantage a direct descendant bears vis-a-vis the outsider in his relationship with God. The halakhic source for the primary directive of imitatio de $i$ is the exact same phrase "and you shall walk in His ways" (Deut. 28:9) ${ }^{29}$ What is crucial is that in this instance the referent is God and not Abraham. When the genetic descendant complies with this directive, Abraham is, in a sense, an obstacle to its

25. MT, Avodat Zarah 1:3.

26. On this excerpt some of the standard English translations such as Twersky's, supra note 1, collapse what I take to be two classes of people, i.e. converts and gentiles who profess the unity of God, into one class of converts who profess the unity of God by omitting the second all $(\mathrm{kol})$ in the clause. For a cogent argument in support of my reading see Lawrence Kaplan, "Maimonides on the Singularity of the Jewish People," Daat 15 (1985) pp. v-xxvii at pp. xix-xx, notes 26-28. I also am in total agreement with his interpretation of the phrase "as it is written in the Torah" as descriptive and not prescriptive.

27. MT, Yesodei Hatorah, 1:3-6.

28. Shilat, p. 234, lines 7-8.

29. See MT, Hilkhot Deot 1:5-7. 
accomplishment. He can never be certain that what he is engaged in flows from some ancestral or tribal allegiance or from a rational appreciation of how God operates in the world. The virtuous life appurtenant to "walking in His ways" is one that is played out in the theatre of the mind. The "walking" of Deut. 28:9 figuratively advances "without in any way moving a body." 30 Only the convert's journey along this path originates in the mind. $\mathrm{He}$, therefore, can be confident that his final destination will also be of the mind.

The citation of Gen. 18:19 to establish the convert's credentials further fortifies his induction into Abraham's nuclear family (benei beto). Its relatively frequent appearance in the Guide ${ }^{31}$ serves to reconfigure its contours when cited elsewhere. The chapter dealing with the concept of "trial" (nisayon) (III:24) culminates, of course, with its most powerful instance, the binding of Isaac. One of its purposes, we are told, is to validate the truth and certainty of prophetic revelation, which, for the prophet, is of equal status in clarity of perception "as that of all existent things that are apprehended through the senses or through the intellect." ${ }^{2}$ Otherwise Abraham would not have proceeded with such dispatch to implement that, "which is repugnant to nature." 33 Gen. 18:19 is then cited to demonstrate that Abraham communicates ideas through action as well as oral teaching, "just as they followed his correct and useful opinions, namely, those that were heard from him so ought one to follow the opinions deriving from his actions especially from this action." The aqedah is transformed into a parable conveying theoretical truths whose narrative crux is the relationship between a father and son. Those who can trace their lineage back to Abraham are more prone to interpret the trial in terms of its paternal/filial dimensions, a hermeneutical stand coloured by their own emotional and familial bond to the central characters. ${ }^{34}$ On the other hand, the convert, who lacks such a bond, and is detached physically from the personalities involved, can more easily divorce the theoretical from the existential. The absence of a father/son lens through which to view the story enhances its theoretical import. The convert's vantage point not only gains him more direct access to Abraham's oral teachings but also to his behavioral teachings.

30. Guide, I:24, p. 54.

31. II:39; III:24; III:43; III:51.

32. Ibid, p. 501.

33. Ibid, p. 502.

34. Such a stance would make them more amenable to readings of the story concentrating on its ethical dimension such as Kierkegaard's and his "teleological suspension of the ethical" which, I believe, would be anathema to Maimonides' view. See Guide I:54, p. 125 for the essential bond between a father and son "that is attached to compassion, pity and an absolute passion..." When God is described in terms of father/son relationships, though, one must view the manifestation of these emotions as arising dispassionately. 
By virtue of the figurative father/son construct, the convert can also legitimately lay claim to those concrete benefits that flow from the promises made by God to Abraham. Since Abraham was granted the land of Israel (Gen. 13:17), that grant extends to the convert enabling him to declare, "who has allotted our fathers." ${ }^{35}$ However, prayers, which allude to post Abrahamic historical interventions by God on behalf of Israel, pose more serious problems for the convert. Phrases such as "who took us out of Egypt" and "performed miracle for our fathers" are left to the personal prerogative of the convert. He can adopt or amend in accordance with his degree of comfort in appropriating the Israelite national historical consciousness. ${ }^{36}$ Ultimately though, even these ethno- specific references need not be altered ("who took Israel out of Egypt;" "who performed miracles for Israel") to ritually perpetuate the convert's otherness. The assumption of his new identity is consummate since he has "come under the wings of the Divine presence and joined (nilveta) God there is no distinction at all between us and you..." ${ }^{37}$. To expressly distinguish himself would even contravene a prophetic affirmation of his unconditional assimilation into the fold, "Neither let the son of the stranger, that has joined (nilveh) himself to the Lord speak, saying "The Lord has separated me from His people" (Isa. 56:3). Isaiah's pronouncement would be particularly comforting for Ovadiah since it is secured by the prospect of a universal pilgrimage to the Temple that is defined as a "house of prayer (tefilah)." That house is welcoming to all who share a common belief entitling them to "rejoice in my house of prayer... for my house will be called a house of prayer for all nations." (56:7). Prayer, which for Ovadiah was initially divisive, is, in Isaiah

35. This phrase appears in the post-meals blessing, the birkhat hamazon. See also MT, Hilkhot Bikkurim, 4:3. For a halakhic opinion in disagreement with this position as the convert has no share in the land see Tosafot's cite of Rabbenu Tam's ruling in BT, Baba Bathra, 81a (lead word-limeute).

36. Michael Nehorai, in his review of Kellner's book, supra note1, in Daat 30 (1993) pp. 127-129 (Heb.) at p. 129 points this out in criticism of Kellner's general thesis. He claims that this part of the ruling can be interpreted either way, "however, it is impossible to refute one who claims that the Rambam, despite all the love he manifested for Ovadyah the convert, still did not entirely erase any distinction between him and the naturally born Jew." To my mind this part of the ruling in no way weakens Kellner's thesis. First of all, in the very next breath Maimonides asserts "there is absolutely no difference between us and you for any matter." Secondly, Kellner's thesis can admit of some halakhic differences, even according to Maimonides, however they are not grounded in ontological difference. This particular dispensation for a discretionary altering of prayer merely caters to the particular comfort level of the convert. I do not believe there is any way in which this can be read to endorse an essentialist view of the convert.

37. Shilat, p. 234, lines 14-15. Jose Faur interestingly traces the scriptural roots of this concept to the obligation of a proselyte to offer a Paschal sacrifice just like the native Jew in Ex. 12:48-49. See his Homo Mysticus: A Guide to Maimonides' Guide for the Perplexed (Syracuse Univ. Press, Syracuse, 1998) p. 232, note 21. 
56 , transformed into a supreme symbol of unification both for the convert and ultimately all of mankind. ${ }^{38}$

The term nilveh (joining), used by the response in both its description of Ovadyah's unconditional attachment to Judaism and in its choice of prooftext (Isa. 56:3), is instrumental to its rationale. Firstly, its object is consistently God, not the Jewish people. ${ }^{39}$ His ability to fully participate in communal practices such as prayer is dictated by his acceptance of the universal-the unity of God. The foundations of the Jewish nation were in fact rooted in its universal message. Thus, the goal of the evolutionary process of nation building originating with Abraham as charted by the Mishneh Torah, is also a universal one. Jewish demographic growth conveyed by the term nilvim or a swelling of the ranks with new members continued to be promoted by Abraham's moral and intellectual heirs Isaac and Jacob:

\begin{abstract}
"Isaac settled, teaching and restoring. He, in turn, informed Jacob and appointed him to teach and be settled down teaching and restoring all those who have joined themselves (nilvim) to him.... and so it evolved and strengthened among Jacob's children and those who joined themselves (nilvim) to them and there was formed in the world a nation that knew God." ${ }^{40}$
\end{abstract}

The national cohesiveness of the Jews is grounded in a common intellectual enterprise that knows no ethnic or geographic boundaries. Their absorption of others via the process of nilvim orients them toward an identity, which actually transcends the parochialism normally associated with national aspirations. "Knowing God" is a universally accessible ideal which, at its inception, already contemplates the utopian messianic unity of purpose and will in this same enterprise envisaged at the very end of the Mishneh Torah when "there will no longer be any concern in the world but to know God." 41

A term, which already biblically expressed the assumption of Jewish identity by outsiders, ${ }^{42}$ determines that identity by its very absence of specificity. It is therefore particularly apt for Ovadyah's admission into the

38. See Guide III:45 where the original location of the Temple to be was concealed to prevent divisiveness on a global and tribal scale. III:46 also suggest that one of the reasons for the annual Temple pilgrimages was to promote "fraternity."

39. Shilat, p. 234, lines 14, 16 and p. 235, line 18. For a contrasting expression capturing the nationalist element of the conversion see the end of the third response to Ovadiah regarding Islam at p. 240, line 13 "and has attached (nidbaq) himself to this nation."

40. Avodat Kokhavim, 1:3.

41. Melakhim, 12:5. See also Hilkhot Shemitah VeYovel 13:13 which renders God and ultimate reward, both in this world and that to come, universally accessible "to each and every individual who has entered the world." The only prerequisites are an all-consuming dedication to God and detachment from material concerns.

42. Esther 9:27. 
fold. Assimilation into a family that recognizes no distinction in terms of common practice, whether it is joy during festivals ${ }^{43}$ or prayer in the times of sorrow, ${ }^{44}$ is its Maimonidean definition. Adherence to the Jewish faith gains recognition as a "brother" thereby attracting social obligation. The entire nation is considered to consist of "children of God." 45 Biblical precedent for the figurative use of familial terms paves the way for co-opting Ovadyah into the family. The effacement of any lines of division carries over internally to a pervasive equality among all individuals of Israel since "they have joined God and behave in the principle of religion." 46

Maimonides' rationale for the parity between Jew and convert cannot be fully appreciated without a consideration of the philosophical underpinnings of his position. These are of utmost relevance when addressing issues raised by prayer, itself problematic for its God-directed language of attribution and personalization. The picture of God that is reflected in a being that is addressed, queried, adorned with human traits, and historically interactive is in fact a false one. The hallmarks of prayer, petition and supplication, are based on a conception of a responsive deity. Response implies change thereby violating the concept of unity. Whether two inconsistent notions of prayer, one traditional and dialogic and the other philosophical and contemplative, can ultimately coexist, has been thoroughly canvassed in previous scholarly studies. ${ }^{47}$ For the present purposes it is not necessary to enter into the debate but merely to point out that, regardless of which side of the debate one aligns oneself with, traditional notions of prayer cannot be sustained at the cost of an idolatrous corruption of God's nature. The very minimum that every worshiper must be cognizant of during prayer is that its anthropomorphic language is a concession to the limits of human

43. Shevitat Yom Tov 7:17, "Every man is obligated to rejoice in them, including him, his children, his spouse, his family members and all those who have joined themselves (nilvim) to him."

44. Taaniyot 4:4. Those qualified to pray during public fasts are those whose "children, family members and all close to him who have joined themselves to him" are ethically pure.

45. Matanot Aniyim 10:2. "All of Israel and those who have joined themselves to them are like brothers...." Clearly, his inclusion of outsiders on this score negates an essentialist view of moral traits. To be charitable is to act charitably. There is no inborn Jewish trait of charitability. See M. Kellner, "Was Maimonides Truly Universalist?,” Trumah 11 (2001) pp. 3-15, at pp. 9-10.

46. Rozeah 13:14.

47. See for instance two opposing positions represented by Marvin Fox, supra, note 7 and Ehud Benor, Worship of the Heart: A Study in Maimonides' Philosophy of Religion (SUNY Press, Albany, 1995). There are basically three approaches to the problem typified by the following scholars:

Fox-dialectical tension.

Benor-unified coherence.

Reines - esotericist incompatibility. See his "Maimonides' True Belief Concerning God," in Maimonides and Philosophy, eds, S. Pines and Y. Yovel, (Dordrecht: Martinis Nijhoff, 1986) pp. 24-35. 
understanding just as that of the Torah itself. What motivated the men of the Great Assembly to standardize prayer in this way was both historical and psychological. The former was a consequence of the decline in popular facility with $\mathrm{Hebrew}^{48}$ and the latter was the "necessity to address men in such terms as would make them achieve some representation-in accordance with the dictum of the Sages: The Torah speaks in the language of the sons of man." ${ }^{49}$ Once this maxim is operative within the canon of prayer, as it is in that of Scripture, then one is not confined to the narrow straits of literalism. Terms such as "father" can imply a pedagogical model and the door has been opened to invite the outsider into its figuratively appointed domain.

From a philosophical perspective the same reasoning would hold true for recalling "the miracles performed on behalf of our father." Once again conversion blurs the lines of distinction to the extent that "no difference exists between you and us, and all miracles done to us have been done, as it were ${ }^{50}$ to us and to you. ${ }^{" 51}$ Miracles, as traditionally understood, pose philosophical problems for Maimonides since they disrupt the stability of the natural order. They also undermine the integrity of the radical unity of God and all that it entails regarding His nature such as immortality, eternality and knowledge of universals. Their impact on the rigid requirements of absolute unity is softened by relegating them to the world of natural phenomenon distinguished only by their rarity of occurrence ${ }^{52}$ Such being the case, miracles are not to be considered as historically conditioned divinely mandated lapses in the natural order. Since they do not signify a divine response to historical events, references to them in prayer and blessings are devoid of any temporal sense. They therefore can only be pronounced figuratively even by those born into the fold. Once the convert has "joined himself to God," which means he has subscribed to the oneness of God as laid out in the Guide, then he can just as legitimately adopt the figurative reminiscence of miracles. The "as it were" of the performance of miracles "to us and to you" refers to both "us" and "you." Both must equally understand these phrases in an "as it were" fashion.

Maimonides then moves from phrases burdened with national history and ancestry to those with Israel's ground of election. "Who chose us;"

48. MT, Hilkhot Tefillah, 1:4. See Gerald Blidstein's discussion in his Prayer in Maimonidean Halakha (Heb.) (Mossad Bialik, Jerusalem, 1994) pp. 34-48.

49. Guide, I:59, p. 140.

50. Shilat's preferred reading over another version which changes one letter to render the phrase "as it were" to "in these."

51. Ibid, p. 234, lines 14-15.

52. See his commentary to the Mishnah in Avot 5:6 regarding ten miraculous events "created" during the twilight hours of the sixth day of creation. According to Maimonides, these are particularized by their specific time of input but are emblematic of all miracles having been pre-programmed at Creation, only at different intervals of the Genesis account. 
"Who granted us;" "Who separated us" ${ }^{33}$ relate to Judaism's foundational document, the Torah. It is the gift of the Torah that singled Israel out from the community of nations. As the convert has wholeheartedly decided to submit himself to the legal regime of the Torah, he has tethered himself to the very source of Israel's chosenness. That source is universally accessible and issues an open invitation to all who wish to reenact the Sinaitic moment of "conversion." 54 At this juncture in the response Maimonides strategically retraces the spiritual and intellectual decline Israel experienced prior to its "election" at Sinai. "Know, that our fathers who exited Egypt were largely idolaters while in Egypt, they became assimilated with the nations and adopted their behavior until the point God commissioned Moses ..." "55 For all intents and purposes the Israelites had become Egyptians acculturating themselves to their religion and customs. What Maimonides has achieved with this is an interruption in the straight line between Abraham and present day Jews. The Egyptian debacle sets up a historical barrier between the latter and Abraham. The Egyptian Jews had alienated themselves from their Abrahamic heritage to the extent that they could no longer legitimately lay claim to their ancestral roots. ${ }^{56}$ Desperately in need of conversion

53. It is not clear as to which blessing or prayer this particular phrase alludes to. See Shilat, p. 233, note 6.

54. The polarization between the Maimonidean and Halevian positions can be no more conspicuous than on this point. The special amr ilahi (the ontological sign of election) that attaches to the nation of Israel can only be transmitted hereditarily, as he makes quite clear in his Kuzari, "Anyone from the nations of the world who accompanies us and converts, may the Lord be gracious to him as He is to us, is not brought to our level." (I:27). It is on this basis that Halevi disqualifies the convert from ever achieving prophecy since "... he is not comparable to an Israelite from birth. For only an Israelite by birth is eligible to become a prophet" (I:115). For a discussion of the opposing schools see Baruch Frydman-Kohl, "Covenant, Conversion and Chosenness: Maimonides and Halevi on "Who is a Jew?,"” in Judaism 41,1 (1992) pp. 64-79. For Halevi's position in particular see Daniel Lasker's "Proselyte Judaism, Christianity, and Islam in the Thought of Judah Halevi," JQR 81 (1990), in which he conjectures that the rabbinic statement in BT Kiddushin 70b confining the shekhina's domain to the native born Jew influenced his position (p. 90).

55. Shilat, p. 235, lines1-2. Haim Hillel Ben-Sasson has characterized this segment of Maimonides' historical survey as a transformation of Israel into "a nation of converts, as it were, for the second time in their historical development," in "The Uniqueness of Israel According to Twelfth Century Thinkers," P'raqim (Schocken Institute Yearbook) 2 (1969-74) (Heb.) pp. 145-218 at p. 186.

56. The historical breach with Abraham is captured by the MT, Avodat Zarah $1: 3$ where the Israelite apostasy is described as resulting in "the principle which Abraham planted was uprooted and the children of Jacob reverted to the error of the nations and their waywardness." Moses then arrives on the scene to "crown them with mitzvot" that is to impose the law and its sanctions. See also Guide II:39 for the distinction between Abraham the instructor and Moses the lawgiver. See also the last chapter of my book, Maimonides and the Hermeneutics of Concealment (SUNY Press, Albany, 2002) pp. 159-162. 
themselves, the figure of Moses intervened in his capacity as legislator rather than persuader. ${ }^{57}$ Israel's election is rooted in Law and the Jew's claim to his uniqueness is through his submission to the Law. This feature also signals the convert's transition to his newly adopted faith. His allegiance to the Law links him to Moses and Sinai and enables him to voice those prayers, which give expression to that link through chosenness. His allegiance to the mind, however, overcomes the legislative barrier to Abraham as his father.

In support of the proposition that the giving of the Law at Sinai contemplated not just the audience at hand but all potential converts in the future Maimonides cites Numbers 15:15, "One ordinance (huqah) shall be both for you of the congregation and for the stranger that lives with you, an everlasting ordinance, as you are so shall the stranger be before the Lord." The last phrase is operative in rendering the convert and the Jew equal before the law. The formal process of initiation into the Jewish faith is halakhically derived from this very verse. ${ }^{58}$ Israel's performance of circumcision, ritual immersion and sacrifice in anticipation of the reception of the Torah at Sinai is the model for all future converts for "as you are so shall the ger be." Numbers 15:15 mandates a reenactment of Israel's transition from a state of almost total assimilation to one of normative uniqueness. Maimonides' halakhic codification of this requirement is prefaced by a historical account of Sinai being, in a sense, phased in by these three rituals of acceptance. ${ }^{59}$ The trading of identities for the convert is realized by the summoning of a past and an anchoring in the present thereby appropriating a common history.

Numbers 15:15 also provides the exception to the exclusive endowment of Israel with the law granted by Deut. 33:4, as a "heritage of the congregation of Jacob." This verse, according to Maimonides, singles out

57. For the argument that Moses is quite literally the author of the Law (its particulars and conventions) whereas its divine origin is informed by its purpose and aims see Kalman Bland, "Moses and the Law According to Maimonides," in Mystics, Philosophers and Politician, eds, J. Reinharz, J. Swetschinski (Durham, N.C. Duke Univ. Press, 1982) pp. 49-66.

58. BT, Keritot 9a.

59. MT, Issurei Biah 13:1-4. As an example of Maimonides' theology of conversion being perpetuated by future generations of his disciples, H.H. Ben-Sasson, supra, note 55, cites the thirteenth century exegete David Kimhi's comment to Gen.17:1 that, "those foreigners who enter into the covenant of Abraham and the teaching of God are considered Abraham's progeny and are included in hamon goyim, that is Abraham is father to them." Yet, I would note, that even such a staunch adherent of Maimonidean teachings expressed some ambivalence on this point, for in the beginning of his comments to this very same verse he offers the following rationale for the timing of Abraham's circumcision; “... and he was commanded to undergo circumcision prior to conceiving Isaac in order that Isaac should originate from a seed that is more kasher..." 
Moses' exclusive legacy to Israel, and Israel alone, "Moses, our teacher, allotted the torah and the commandments solely to Israel." ${ }^{\circ 0}$ However, he continues, that allotment is also available "to all who wish to convert from the other nations" by virtue of Numbers 15:15, "as you are so shall the stranger be." This verse establishes a juridical equality between all those within the jurisdiction of Judaism since, as the next verse continues, "there will be one teaching (torah) and one law (mishpat) for you and the stranger (ger) who lives with you."

The operative term mentioned in Num. 15:15, under whose legal rubric the convert is subsumed, also determines the telos of law and the natural order. Though torah, hoq and mishpat all refer to a concrete set of subjective conventions that constitute the mitzvoth, they also reflect abstract notions about existence as a whole to which the convert is attuned by his developed sense of reason. The general aim of torah is to "offer guidance toward what is correct" to "all those who seek guidance." 61 The convert certainly fits in to this latter class of people. Maimonides' definition of torah forms an introduction to his discussion of understanding the end of all of creation. That understanding is limited to the functionality of all its constituent parts as "conforming to its purpose" but not to its "final end." 62 To presume that one can discover the "final end of His volition," would be a futile endeavor for any existent consisting of inferior matter. The convert has already arrived at this notion by his abandonment of any culture premised on the ability to determine "His volition" and therefore control him. His preference for the torah may be motivated by its primary telos to "put an end to idolatry, to wipe out its traces and all that is bound up with it, even its memory as well and all that is bound up with it. ..."63

The concomitant of acknowledging one's limits with respect to the final end of creation is the duty to discover that end for the Law. What affords the Law its integrity is its intelligibility. Primary principles of justice, morality, politics and philosophy underlie the entire system of mitzvot whether classified as huqim or mishpatim. ${ }^{64}$ The only distinction between the latter two categories of law is the relative ease with which their respective utilities can be discovered. ${ }^{65}$ Surely the lure of Judaism for the medieval convert, grounded, as it can only have been, in reason, would have found this feature of the Law as a whole an attractive one. Once he rationally formulated the basic tenets of Judaism, existence and unity of God, he adopted all the

60. MT, Melakhim 8:10.

61. Guide III:13, p. 453.

62. Ibid; p. 454-455.

63. Ibid, III:29, p. 517.

64. Ibid, III:31, p. 524.

65. Ibid, III:26, p. 507:

mishpatim = "utility is clear to multitude."

huqim = "utility not clear to multitude." 
mitzvoth, which, in one fashion or another, act as their safeguards. ${ }^{66}$ In this sense the convert, experientially and intellectually, mirrors what transpired at Sinai. According to Maimonides, everyone present heard the first two commandments, since "the existence of the deity and His being one, are knowable by human speculation alone." 67 On the other hand, the rest were heard exclusively by Moses and then related to the nation since "they belong to the class of generally accepted opinions and those adopted in virtue of tradition not to the class of the intellecta." ${ }^{\circ 8}$ The audience at Sinai, just as the convert, reasoned the fundamentals of religion and then accepted their conventional safeguards on the basis of Mosaic authority ${ }^{69}$ The convert, by his precise replication of the Sinaitic revelation, can, without reservation, consider himself 'chosen' and a recipient of God's 'giving.'

Numbers 15:15 is also the critical prooftext in support of the jurisprudential principle that the Law, in its promotion of general societal utility, caters to the majority. It does not, and cannot, contemplate those rare individuals for whom conformity to the Law is in fact detrimental. Just as it is invariably applicable to all its subjects, it is also not temporally or geographically contingent. The verse is cited to substantiate the immutability of the Law as "matters that are primarily intended in the Law ought not to be dependent on time or place; but the decrees ought to be absolute and universal ..." ${ }^{70}$ Even within its own constituency the Law cannot address the needs of the wide array of human psyches and temperaments and yet those isolated individuals cannot deviate or absolve themselves from abiding by it. This proposition is drawn into the rationale of Maimonides' response by virtue of the common prooftext. It also argues for the convert's conformity to every detail of the law but from the perspective of the Law itself. Though, on occasion, the liturgy may not precisely fit the unique circumstances and human condition of the convert, it should not consonantly be altered. The convert, then, contributes to the preservation of the Law's integrity by minimizing exceptions that, if prolix, would lead to anarchic deterioration.

Maimonides then adds a note of encouragement to Ovadyah, which though extra-legal, is consistent with the tenor of his argument developed thus far. The roles are now reversed. Lack of ethnic pedigree is actually superior to its presence for "we can only trace our lineage back to Abraham,

66. See MT, Issurei Biah 14:2 where Maimonides directs that the prospective convert be introduced to Judaism first and foremost with the principles of divine unity and prohibition against idolatry. Only these philosophical teachings are conveyed to him "at length." Once the philosophical groundwork is laid he is advised in stages as to the particular mitzvot and consequences for their violation.

67. Guide, II:33, p. 364.

68. Ibid.

69. M. Kellner makes essentially the same point in "Choseness, Not Chauvinism: Maimonides on the Chosen People," in A People Apart: Choseness and Ritual in Jewish Philosophical Thought, ed. D. Frank, (SUNY Press, Albany, 1993) pp. 61-62.

70. Ibid, III:34, p. 535. 
Isaac and Jacob-whereas you can trace it to He who spoke and the world came to be." 71 The naturally born Jew's faith is always suspect since one can never be certain whether adherence to the faith is not somehow motivated by familial allegiances. The convert's intentions however, like his archetypical predecessor, Abraham, are not subject to challenge since he arrived at the essential truths of Judaism by reason. Tradition and upbringing played no role in his acquisition of the truth of God's existence and oneness. Therefore his relation to God is direct, free of extraneous cultural and social factors.

Reference to God in this part of the response as the one "who spoke and the world came to be" is particularly apt for it appears often in the context of a direct and unmediated knowledge of God. In Hilkhot Deot 3:9, Maimonides fixes this referent as the contemplative object of the stars and spheres who are unceasingly cognizant of "he who spoke and the world came to be."72 A consequence of this cognition is a virtual compulsion to "praise and glorify their creator," adapting the language of prayer to describe their activity. ${ }^{73}$ The Guide credits the spheres with the ideal prayer mode of "praising God and making known His wonder without speech of lip and tongue," superior to verbalization in its purity of thought and pristine representation. ${ }^{74}$ Aside from its connotation of direct knowledge of God, it significantly impacts on the issue of prayer for the convert. What is critical is what the convert has perceived within the confines of his mind. Translating it into audible form is merely a utilitarian distraction ${ }^{75}$ from the ultimate goal of self-representation. Transition from thought to speech is born of expediency and signals a distancing from the perfection of representation. Prayer, like sacrifice, is a concession to the exigencies of human nature that cannot tolerate worship exclusively as silent meditation. ${ }^{76}$ Therefore, once the convert himself is plunged into that concessionary domain, words must be acknowledged as pliable and susceptible to the kinds of configurations biblical anthropomorphisms are.

Another crucial reference to the one who spoke and the world came to be also appears within a context of direct knowledge of God arising out of philosophical reflection. Probing the vast expanses of all of creation in order to extract its limitless ingenuity and complexity fulfills the halakhic obligation to love God. Hilkhot Yesodei Hatorah 2:2 then attributes the same

71. Shilat, p. 235, lines 5-6.

72. See also Guide, II:4 for the notion that "all spheres are living bodies, endowed with a soul and intellect, having a mental representation and an apprehension of the deity..." p. 259, adopted by the MT.

73. See MT, Tefilah, 1:2-4 where praise (shevah) is the core sentiment expressed in prayer.

74. Guide, II:5, p. 260.

75. Ibid., Praise through speech "are meant to instruct someone else or to make it clear concerning oneself that one has had the apprehension in question."

76. See Guide, III:32, p. 526 where prayer is the rabbinic analogy to the "divine ruse" of sacrifice. 
liturgical impulse to this enterprise as it did to the heavenly bodies. One who has undertaken this penetrating contemplation of the wonders of the universe is overwhelmed by the emotional desire to "praise and glorify" God. This path toward the love of God is consistent, Maimonides says, with the rabbinic maxim regarding love that "as a result you will acknowledge the one who spoke and the world came to be." The reference to this divine epithet conveys to the convert that he in fact has aspired to the essence of prayer as it emerges from the longing to know God rationally. ${ }^{77}$ In this he has also emulated his figurative ancestor, Abraham, characterized by Maimonides as the quintessential "lover" of God "who serves God exclusively out of love."78 Perhaps this provides the sense in which the specific commandment to love the convert (Deut. 10:19) is analogized by Maimonides to the obligation to love God (Deut. 11:1), "One is commanded regarding the love of the convert just as one is regarding the love of Him." ${ }^{79}$ Abraham as "lover" of God is personified in every convert who provides a concrete model for the route to follow towards the love of God. Loving the "lover" guides one toward the divine object of desire.

God, in his capacity as He who spoke and the world came to be, appears in two additional halakhic settings. ${ }^{80}$ Both are instances in which Maimonides appeals to this divine force in order to provide additional impetus for fulfilling certain halakhic obligations. In the first case, the care and sensitivity

77. As Howard Kreisel has argued in "Love and Fear of God in Maimonides' Thought," (Heb.) Daat 37 (1996) pp. 127-151, the reason the second book of the MT is entitled the Book of Love is "in order to let it be known that these mitzvoth are merely the Jewish framework in which the Jew aspires to human perfection." (p. 147) The latter is a universal goal of all mankind, i.e. knowledge of what can be known. The ideal love of God, as defined in Yesodei HaTorah 2:1, is formulated as the goal of man qua man and not of the Jew in particular. The fact that a large portion of the Book of Love is taken up with laws relating to prayer and blessings is instructive for the Jew in how to Jewishly cultivate his humanity. To distinguish the convert in these rites would be to promote an elitist view of them. This would ultimately be self defeating.

78. MT, Teshuvah, 10:2.

79. MT, Deot, 6:4. See also Sefer Hamitsvot, Positive Commandment \#207. Deot 6:4 concludes with a biblical prooftext establishing God's personal love for the convert. The reciprocal relationship I have outlined here corresponds to the philosophical construct of reciprocity in the Guide, III:52, p. 629:

"... the king who cleaves to him and accompanies him is the intellect that overflows toward us and is the bond between us and $\mathrm{Him}$, may $\mathrm{He}$ be exalted. Just as we apprehend Him by means of that light which $\mathrm{He}$ caused to overflow to us ... so does He by means of that selfsame light examine us."

80. The expression also appears in the MT as the object of blessing at the very end of the MT for having afforded Maimonides the opportunity to see through his great code (hahibbur) to its intended completion. Other than that it is also part of the standardized daily liturgy as recorded in the Seder Hatefilot Kol Hashanah. 
with which orphans must be treated is ensured by the personal interest God takes in their condition as evidenced by "the covenant He who spoke and the world came to be entered into with them." ${ }^{81}$ The second guarantees the almost boundless extremes one must go to in the manner one treats parents. Fear and respect is due them even at the cost of personal humiliation and insult. If obedience to such standards of behavior was forthcoming had they been promulgated by royal decree, how much more would such obeisance be expected if they emanate from the one who spoke and the world came to be. ${ }^{82}$ The universal connotations of this divine characterization are foregrounded by its appearance in the context of the law demanding respect for parents. That is the one obligation, which, according to Maimonides straddles the convert's former life as a non-Jew and present one as a Jew. ${ }^{83}$ His ruling is jarring both for its disregard of the halakhic rupture of the convert from his heredity, ${ }^{84}$ and for its lack of support in the halakhic sources. ${ }^{85}$ The choice of divine characterizations to appeal to in the response to Ovadyah could not have been more suitable. Its juridical setting is of a law that is incumbent both on the Jew and non-Jew by virtue of their shared humanity. Directing Ovadyah's attention then to the one who spoke and the world came to be impresses upon him his ontological identity with his newly adopted coreligionists. $^{86}$

In both instances this singular divine referent is invoked to address situations involving an absence or presence of parents. The comfort provided to the convert by its identification as his direct ancestor is significantly augmented by its halakhically charged nuance. The convert, like the orphan, is considered bereft of parents by virtue of being "born again." 87 God places himself personally in locus parenti to the orphan in order to compensate for his particular vulnerability. ${ }^{88}$ Tracing the convert's antecedents back to God himself not only serves to console him for his ethnic deficiency

81. Deot 6:10. Of relevance to our response is that Maimonides attributes particular divine receptivity to the orphan's prayers to this covenant.

82. Mamrim 6:7.

83. Mamrim 5:11.

84. He is considered to be Keqatan shenolad dami (like a new born child). See BT, Yevamot 91b.

85. See Joseph Karo's comments on this ruling in his Kesef Mishneh regarding his difficulty in finding a source for it.

86. See G. J. Blidstein, "Parents and Children in Maimonides' Philosophy and Halakha," Daat 37 (1996) pp. 27-36 who argues that this ruling demonstrates Maimonides' view of parental respect as a universal norm. However his awareness of the paucity of halakhic sources manifests itself in his narrow construction of its scope for converts, i.e. the standard is only partial respect (miqtsat kavod).

87. Supra, note 83 .

88. See also Moses ben Nahman's (Nahamanides) reasoning as to the severity of the consequences for maltreating proselytes and orphans in his commentary to Exod. 22:20. Their lack of natural protectors is compensated for by God's personal guardianship. 
but substitutes God for his biological parents as his protector due to his socially inferior station. Any slight against the convert, such as assigning him a kind of second-class status with respect to prayer, is also one against God who is both the convert's lover and parent. The demands of parental fear and respect, imported to the response by the divine reference, are acute when one considers Maimonides' sentiments expressed in his third response to Ovadyah regarding behavior toward the convert. The gravity of the obligation to love and fear parents and obey the prophet pales in comparison to what one is burdened with when it comes to the convert "since it is possible to respect a person and fear and listen to one who is not loved, however we are commanded to love the convert, an emotion consigned to the heart. ..." 89

Curiously, it is only after Maimonides has provided a theological and philosophical rationale for his decision that he resorts to concrete halakhic principles. The mandatory recitation that accompanies the donation of the first fruits (bikkurim) during the Temple period poses the same problems with respect to the convert. It is genealogically and historically particular charting, as it does, the development of Israel from its inception in the patriarchal period through the Egyptian enslavement and liberation and climaxing with settlement in the promised land "as promised by God to our fathers." (Deut. 26:5-10). Included in the Mishnah among those who are required to donate but do not have the capacity to recite is the convert. ${ }^{90}$ Although this is an anonymous Mishnah recording an undisputed opinion Maimonides rejects its authority in favour of the Palestinian Talmuds' ${ }^{91}$ to the contrary. The latter reasons that Abraham's progeny, by virtue of Gen. 17:5, is not restricted to his biological line but rather to all those "who seek protection under the wings of the divine presence." 92 His codification of the Palestinian Talmud's stand in the Mishneh Torah is imported into the response, halakhically reinforcing what has been ideologically argued up to this point.

Menachem Lorberbaum has argued that the response is structured to "show how the legal precedent naturally flows from his theological position

89. Shilat, p. 240, lines 7-9.

90. Bikkurim 1:4.

91. Ibid. Maimonides was partial to citing the Palestinian Talmud in his Code and his resourcefulness in its use is aptly described by I. Twersky, "Maimonides' reliance upon it in his Mishneh Torah is unusually bold and extensive." In his Introduction to the Code of Maimonides,vol.xxii, Yale Judaica Series (Yale Univ. Press, New Haven, 1980) p. 10.

92. MT, Bikkurim 1:3; Perush Hamishnayot, Bikkurim 1:4 where the formulation is that "Abraham is the father to all who enter the world since he has taught them the true belief and religion." See Kafih's note 13 on p. 417 of the volume of Seder Zeraim which suggests that this may have been inserted consequent to the response to Ovadyah since the entire reference to the Palestinian Talmud is missing from the first edition of the Perush. 
and exhibits how positive law reflects broader religious values in Judaism."93 I believe Maimonides has gone much further both from a methodological point of view and from a philosophical one. His code, the Mishneh Torah, is notorious for its silence as to Talmudic sources. ${ }^{94}$ For example, the law at issue regarding bikkurim simply adopts the Palestinian Talmud's ruling without reference to its Babylonian counterpart. Without the assistance of commentators such as Joseph Karo, ${ }^{95}$ the untrained would be unaware that there is any discrepancy. On the other hand, the response makes a point of mentioning the Bavli's position and then, insouciantly, dismisses it with the words, "this is an undisputed Mishnah according to R. Meir, however it is not the halakha, rather it is as expounded in the Palestinian Talmud." "96 This explicit halakhic preference preceded by a theological prologue is meant to apprise the reader of a conscious rejection of one halakhic text over another determined by theological concerns. Written after the completion of the Mishneh Torah, ${ }^{97}$ it is also intended as an explicative gloss to his ruling there and how he arrived at it. Indeed, it may present a key to unraveling his method underlying other rulings in the overall project.

Other than providing an intertext by which to read the Code, Maimonides, by prefacing halakha with theology, invites us to read the halakha philosophically. It is not a separate rationale but blends in with its theological foreground. The essence of the recitation over the bikkurim is, according to the Guide, the ethic of humility. Annual reminiscence of one's humble origins coupled with rabbinic regulations intended to accentuate sentiments of diffidence ${ }^{98}$ are remedial "of the normal qualities that are generally acquired by all those who are brought up in prosperity-I mean

93. See his "Maimonides' Letter to Ovadyah: An Analysis," in Svara vol. 3, no. 2 (1993) pp. 59-66 at p. 64.

94. This was a common criticism leveled against the MT. For but one early example see Rabbi Abraham ben David's of Posquieres in his Hassagot to the introduction of the MT, "He meant to improve but did not improve, for he abandoned the method of all authors who preceded him. They always cited proof for their statements and wrote the statements in the name of those who authored them..."

95. See the comment of the Kesef Mishnah on Bikkurim 1:3. For a list of various rabbinic scholars who either endorse or take issue with Maimonides' position in their respective novellae or responsa see Shaye Cohen, The Beginnings of Jewishness: Boundaries, Varieties, Uncertainties (Univ. of California Press, 1999), pp. 335-36, notes 60-61. As expected, there was virtual unanimity of endorsement among subsequent sephardic authorities whereas the ruling was hotly debated in Ashkenazic circles. For but one example of such debate regarding bikkurim see that conducted between the 12th century tosafists Rabbenu Tam and R. Isaac of Dampierre in BT, Bava Batra 81a, s.v. limutei..

96. Shilat, p. 235, lines 12-13.

97. Reference is made to the hibbur hagadol in the second of his responses to Ovadyah. See Shilat, p. 236, lines 9-10.

98. The bikkurim must be transported on the shoulder of the donor (Mishnah, Bikkurim 3:4). The Guide singles out this requirement as a supreme symbol of humility. 
conceit, vanity and neglect of the correct opinions ..."99 Reference is made to the biblical directive to "remember that thou wast a servant" (Deut. $5: 15 ; 16: 12)$ as affirming the moral design of this type of memory. ${ }^{100}$ Strikingly germane to our letter is the context of this obligatory act of memory, which is intended to encourage fair and equal treatment of the powerless, and vulnerable, among which are "the stranger (ger); the orphan and the widow." 101 The superiority which arrogance breeds leads to the exclusion of the outsider and it is precisely the bikkurim rite that provides its antidote. Because of its position in the response, the law of bikkurim transcends its technical juristic significance to secure the moral posture one must assume vis- a- vis the alien, the convert. The entire letter is one seamless theological, moral, philosophical and juridical argument for the unfettered inclusion of the convert.

In conclusion, I wish to revert to the prooftext cited, immediately prior to the bikkurim section, in support of the notion that the convert has established a direct link to God contra the natural born Jew who relates to the divine via pedigree. Isa. 44:5 delineates various proclamations of allegiance to the nation and faith of Israel, "This one will say 'I belong to Yahweh,' another will declare in the name of Jacob, yet another will write Yahweh's name on the hand and add the name of Israel to his own." Though numerous rabbinic sources divide this verse into four distinct classes of people (Godfearers; purely righteous; converts; repentants), to my knowledge, none of them correlate the first declaration, I belong to Yahweh, to the convert ${ }^{102}$ as Maimonides does. As to whether he consciously altered his source or possessed a variant reading we can never be certain, but the convenience of the modification combined with the number of divergent sources to the contrary tends toward the former contention. Unlike the law of bikkurim, various other rulings in the Mishneh Torah preserve an inferior legal status for the convert in terms of membership in the community. ${ }^{103}$ One in

99. Guide, III:39, p. 551-52.

100. Ibid, p. 552.

101. In Deut. 5:15, it is to allow them rest on the Sabbath and in Deut. 16:12 it is to ensure their participation in the joy of holidays. The term ger here of course does not bear the formal characteristics of later rabbinic converts but it does contain its seeds.

102. See Rashi's comment on the verse who adopts Avot DeRabbi Nathan's set of correspondences; and Masekhet Gerim 4:3; Mekhilta, Mishpatim 18; Targum. A contemporary biblical scholar suggests that all four components of the verse allude to proselytes. See J. Blenkinsopp, Isaiah 40-55, Anchor Bible Series (N.Y., 2002), p. 233.

103. See for example, Maaser Sheni 4:17; Issurei Biah 12:17; Matnot Aniyim 8:1718; Melakhim 1:4. Lorberbaum, supra note 81, deals with the inconsistency between these laws and the letter to Ovadyah by distinguishing between the different genres of responsa and codes. I find the most troubling of those laws to be that of matnot aniyim which sets up a hierarchy of descending priority with respect to the supreme social obligations of charity and ransoming from captivity. The scale of humanity peaks with the priestly class and bottoms out with the convert and manumitted slave. 
particular is justified by the disqualification of converts from constituting "a congregation of God" (qehal yhvh). ${ }^{104}$ The attribution, in the letter, of the first proclamation in Isaiah 44:5 to the convert attenuates the theological and moral implications of the Mishneh Torah's banishment of the convert from God's dominion. What Maimonides has done I believe is no less than explicitly distinguish himself from a position that emerges from his idealized and impartial code of law. When the opportunity arose to encounter the convert within a personal and existential context Maimonides consciously chose to subvert the pejorative implications of the Code. His passion for life managed to displace the detachment of his text. ${ }^{105}$

However, the opprobrium of this "caste" system is immediately neutralized by the addendum that what is determinative of priority is "wisdom" and it is only in the event of equivalence of wisdom that the hierarchy is operative. None of the laws, however, which relegate the convert to a separate legal class, are grounded in an essentialist view of the non-Jew as inferior to the biological one. For instance, the law in Melakhim, barring the convert from holding any political office, can be rationalized by very practical considerations. Its biblical source, Deut. 17:15, is simply, according to Maimonides, a pragmatic directive aimed at staving off tyranny since power in the hands of an outsider is more prone to abuse; "For no individual has ever been the chief of a religious community to whose race he did not belong, without doing it great or small injury." (Guide II:50, p. 615). This is the moral of the biblical episode of the foreign kings who ruled over Edom (Gen. 36:31) the result of which was tyranny and humiliation. See also Hannah Kasher, "Preferential Concern for Kin in Maimonides' Thought," Iyun 45 (1996) pp.115-124 (Heb.) at p. 120.

104. Issurei Biah 15:7 based on BT, Kiddushin 73a.

105. Haym Soloveitchik's analysis of what he perceives as the recent shift in Judaism from a "mimetic" culture to a "text based" one is instructive. In the latter common practice "needs to be squared with the written word." The Letter to Ovadyah was penned by the hand of a master of texts who was also a community activist closely attuned to the existential needs of his constituents. That sensitivity liberated him from the tyranny of the written word to whose theoretical demands he was not always obliged to surrender. See his "Rupture and Reconstruction: The Transformation of Contemporary Orthodoxy" in Tradition 28:4 (1994) pp. 64-130. In a similar vein and more pertinent to our discussion see his "Maimonides' Iggeret Ha-Shemad: Law and Rhetoric," in Rabbi Joseph Lookstein Memorial Volume, ed. (Ktav Pub, N.Y., 1980) pp. 281-319 and especially pp. 305-319 where he characterizes this letter more as a work of rhetoric addressing an urgent situation than a strict halakhic work. 